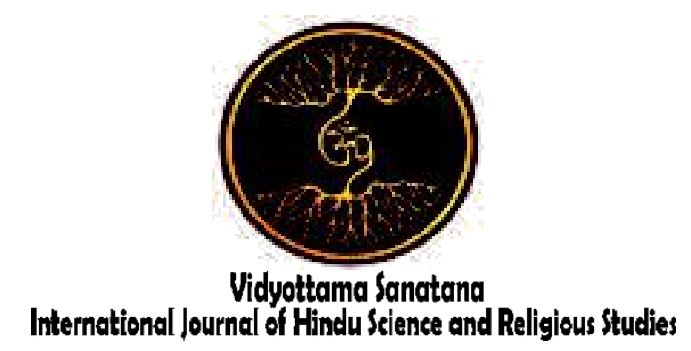

Vol. 3 No. 1 May 2019

\title{
PATIWANGI CEREMONY AT VILLAGE OF SIDAN GIANYAR REGENCY (Gender Education Perspective)
}

\author{
By: \\ Ni Wayan Desi Yuliantari, I Ketut Sumadi, Ni Putu Winanti \\ Institut Hindu Dharma Negeri Denpasar \\ E-mail : desiyuliantari24@gmail.com
}

\begin{tabular}{|l|l|l|}
\hline Received: September 21, 2018 & Accepted: May 21, 2019 & Published: May 31, 2019 \\
\hline
\end{tabular}

\begin{abstract}
Hindu in Bali is never apart from ceremony. Everything they do are always relates to ceremony. Ceremony is one of the way how Balinese people stay close to the God (Tuhan Hyang Maha Esa). From thousands of ceremony in Bali, in this thesis, I am discussing further about 'Patiwangi Ceremoney'. Although this ceremony has been banned from the government's regulations known as DPRD dated on 1951. However, in some village in Bali there are still exists. One of them is in Village of Sidan, Gianyar regency. In deeper meaning some people thought that 'Patiwangi' ceremony is related to gender inequality. This is the basis of writing a thesis title 'Patiwangi Ceremony in village of Sidan, Gianyar Regency, (Gender Education Perspective).

In this study, I am discussing 3 contributor factors. 1. How forms Patiwangi ceremony in village of Sidan District of Gianyar? 2. What is the function of Patiwangi ceremony in village of Sidan District of Gianyar? 3. What is the implication Patiwangi ceremony on gender education perspective in village of Sidan District of Gianyar?

In this thesis, four theoretical concepts are used to answer the problem. The theory of interactionism symbol which is used to analyst form of Patiwangi ceremony, Structural Functional Theory to analyst the function of Patiwangi ceremony, Behaviorism Theory and Gender Theory to analyst the implications of gender education perspective of Patiwangi ceremony. This research conducted in village of Sidan, Gianyar regency. This thesis is qualitative research, using the data collection techniques such as; observation, interviews, documentation, literature, informant determination analysis by purposive sampling and data analysis with qualitative descriptive.
\end{abstract}


From the qualitative descriptive data analysis obtained the following results, 1. Patiwangi ceremony can be explained through the married and ceremony process. Process Patiwangi marriage performed without making a proposal to the bride's parents. This system called 'Kawin Lari. The groom will arrange the place to meet the bride without parents'permission. From the bride's family, parents will then come to groom's house to ascertain that their daughter actually married to the men according to the letter sent. After that the groom's family will telling that their daughter will have the married ceremony based on a good day which is pointed by high prize in Bali called 'Pinandita'. The proses Patiwangi ceremony will begin with 'matur piuning'or asking permission to the God of the sun 'Sanggah Surya'. The bride is praying in front of the temple (Sanggah Surya) while the groom is sitting on the chair waiting for her. After finish, the bride will stand up and the families of the groom will start pouring yellow rice, old Chinese money as a symbol of happiness and prosperity. The families also will throw red 'Endong' leafs as a symbol of purification and eliminate the evil spirit. The ceremony will end with spring of holy water to the bride by the prize (Pinandita).2).The Functions of Patiwangi ceremony, a). Purification, this can be seen from the ornaments of the Patiwangi ceremony such as; yellow rice, old Chinese money and the red 'Endong'leafs as a symbol of the God of Brahma, which is purifying the bride from 'Leteh, Cuntaka, and Evil Spirit. Hence, married within different kast in Bali without Patiwangi ceremony can cause unhappiness. b). Balance, this can be seen from the ceremony itself which is offered to the God as a witness in spiritual, human as a witness in unspiritual and evil spirit ( Bhuta Kala) as a witness in devil's side. The purpose is that after married the bride and groom will get harmonization and balance in life.3). The implication of Patiwangi ceremony, a). Social implication includes changing in social status, parent's status, and the relationship between both families and also the farewell ceremony. $b$ ). psychology implication only happen to the bride, since she is leaving the kasta that she has and followed the groom's kasta.

As per the implication Patiwangi ceremony on gender education perspective, it will be seen on social gap such as; 1). Naming on parents from 'Biang' become 'Dubiang' and 'Aji' become 'Duaji'. 2). Naming on bride from 'Dewa Ayu' become 'Ayu'. 3). The relationship of the bride and parents are no longer as a biological parents, since she has been married with called 'Nyerod' in Balinese language.4). On the farewell ceremony, if one of the parents died, the bride is not allowed to pray if she is pregnant.

\section{Keywords: Patiwangi Ceremony on Gender Education Perspective.}

\section{Introduction}

Hindu in Bali conduct a ceremony almost every day, such as; Dewa Yadnya, Manusa Yadnya, Pitra Yadnya, Rsi Yadnya and Bhuta Yadnya. Manusa Yadnya in this topic is a ceremony which is purposes for purification, education, and culture in spiritual aspect for human being starting from the beginning of pregnancy until the end of live. Referring to Putra (1994: 30), it's said that purification is a must for human being as it is a foundation of self-control, improve and enhance the karma that has been done on the past and present. The tradition is Bali is based on believe and support from all of the societies element and also local culture all over Bali. This is also based on 'Dresta' where ceremony and tradition become stronger in the millennium era and globalization. Hinduism in Bali adopts and selective on every influence on globalization, hence the traditions and cultures existall the time. Among the tradition and culture diversities, in this thesis, will be focusing on one topic, 'Patiwangi ceremony on the gender inequality. 
Gender is a difference between men and women in sexuality behavior. This will be based on opinion of Trisakti, (2002 in Winanti, (2008: 45), said that Gender is a concept where used to identify between man and woman on their social status as well as by law (right and obligation) or from the non-biological aspect.

Partiality and inequalities between men and women always occur throughout life, and women in various meetings in general are still considered to be subordinated, marginal both in structure, concepts and discourses evolving. Hindu religion in Bali, also does not relies there is gender inequality in ceremony activities especially on 'Patiwangi Ceremony'. In relation into past thesis studied, it is also mention that 'Patiwangi Ceremony' is also occurred in gender inequality and is seen to have a uniqueness that needs to be studied more deeply with several assumptions including: 1) Patiwangi Ceremony is abolished in line with the abolition of Asumundung tradition and Alangkahi Karanghulu Paswara DPRD Bali No. 11/DPRD/1951, 2) Patiwangi ceremony is the caste in degradation, 3) Patiwangi ceremony is also caste equality ritual, 4) Patiwangi ceremony is held at the home of the groom, 5) Patiwangi ceremony is identic with using the leaf of endong (red color plants).

Based on above assumptions, this is the basis of writing a thesis title 'Patiwangi Ceremony in village of Sidan, Gianyar Regency, (Gender of Education Perspective). The purpose of this research is to improve the understanding of the meaning patiwangi ceremony by studying gender of education, but need to be analyzed further on form of patiwangi ceremony, ceremonial functions and Implications patiwangi ceremony gender of education perspective in Village of Sidan District of Gianyar.

\section{Methods}

The method of the research is a part of science that discuss or question about ways or procedures in conducting accurate research and systematic (search, notes, formulate, analyze, and to draw up a report) it is related to the existing problems to find something in accordance with the facts or symptoms scientifically. The analyses used in this study were 1) Qualitative and approaches using sociological approaching research. 2) The research location was in Village of Sidan, Gianyar Regency and province of Bali and takes about 3 months, started on February, March and April. 3) Types of data are primary data and secondary and Source of data is an informant and document.4) Instrument Research is individual researcher. 5) Mechanical Informant is using purposive sampling, 6) Data collection methods are observation, interviews, documentation, and literature, 7) Methods of data are analysis descriptive qualitative with the steps: data reduction, classification of data, interpretation of data, and drawing conclusions. 8) Technical presentation and results is in narrative.

\section{Results And Discussion}

Based on data analysis descriptive qualitative research, the results obtained 1) Form of Patiwangi ceremony can be seen on the marriage and the process of Patiwangi ceremony. As for the marriage Patiwangi ceremony process are (1) The process of marriage in different caste is done without making a proposal, but with a system of elopement 'Kawin Lari' where the men reported or sent a letter to Bendesa (the head of Village) from the men's family. Then the Bendesa (head of the Village) will carrythe letter to be delivered to the Bendesa (head of the Village) from the Women's side. (2) The groom then picks up the bride at the place that has been arranged before. (3) At the time they arrive at the front of the hoouse from the groom's side, they will have a small offering called 'natab or angayab segehan cacah' in Balinese language and it's contain a fire placed on the coconut cell. (4) The Bendesa Adat (head of the Village) from the groom's side will come to bride's family and deliver the message that their daughter 
has been married and stayed at the groom's house. (5) The bride's family will come to the groom's house called 'ngetut' in Balinese language to make sure that their daughter is married with the same man as per mention on the letter. (6) The groom's families then will come to the bride's families to inform that their daughter will be married and the ceremony has been a pointed at the good day known as 'Dewasa Ayu' in Balinese language by high prize (Pinandita or Pandita).

The process of the Patiwangi will be as followed: 1). Pinandita (high prize) will conduct the ceremony by offering the offers to the God of Brahma at the Surya Temple, which is named 'Bale Agung' and witnesses by God of the Sun named 'Batara Surya'to be given an approval and spared from calamity. (2) The ceremony than continue where the bride will pray to the God of Surya (Bhatara Surya), the God of Brahma (Bhatara Brahma) as well as the ancestors to ask for an approval that she is married to the other caste 'Wangsa Sudra'or different caste in Bali. (3) The Patiwangi ceremony will start by pouring yellow rice, old Chinese money to the bride by the groom's families. (4).The families also will throw red 'Endong' leafs as a symbol of purification and eliminate the evil spirit. The ceremony will end with spring of holy water to the bride by the prize (Pinandita). 2) The function of the Patiwangi ceremony is to purifying the bride by using the red 'Endong' leafs as a symbol of Brahma in order to clean the female caste who married to men in different caste "Jaba Wangsa" from of all of the 'leteh, cuntaka and evil spirit. The balance of this function ca be seen on the ceremony proses and offering that is offered to the GOD, as a witness in spiritual, human as witness in unspiritual as well as the offered to the Bhuta Kala (evil spirit) as a witness on the evil spirit so that the ceremony goes well entirely. 3). Social implication, such as; 1) In change on the social status and change on the name of the women status. The change on the social status is from 'Dewa Ayu'to 'Ayu'. If the caste of the women is Brahmana and married with the caste of 'Jaba Wangsa' so the women will not be called 'Ida Ayu, Gusti $A y u$, or Dewa $A y u$, anymore and it will bw called just ' $A y u$ '. Because she has been done the Patiwangi ceremony or married with different caste. In Bali well known as 'Nyerod". (2). After the Patiwangi ceremony, calling the parents will also change become 'Dubiang and Duaji'. (3). The relationship betwee the two families will become harmonies, however, the women will not have the same relations as it on the past. (4). The proses called 'Mepamit' on married with different caste can be done at any time as long as the women is not pregnant. If the woman is pregnant the ceremony (mepamit) can be done after the baby is born. 2). Physiology Implication, where women leave their parents to follow the husband is a destiny which is faced by married women and the women must be sincere to have the same caste as the husband. 3).Implication of the Patiwangi ceremony of Gender education perspective is where imbalance differences in gender happened in the naming of parents from 'Biang to Dubiang'from 'Aji to Duaji' and also naming on the bride from 'DewaAyu to Ayu'. The relationship between the bride and the parents will no longer as a biological daughter, since the woman has done the Patiwangi ceremony called 'Nyerod' or lowering in caste and on the ceremony called 'Mepamit' is not allowed to doing it if the woman is on pregnancy.

\section{Conclusion}

Referring to the result of the research on the Village of Sidan, Gianyar regency, is concluded as per such as;1). The form of Patiwangi ceremony in the village of Sidan, Gianyar regency can be explant on the proses and the ceremony of the Patiwangi. 2). Function of the Patiwangi ceremony, there are (a). Self-purification, (b) Balance. 2). Implication of the Patiwangi on gender perspective are, a). Social implications include the changing on the social status, 
parent's naming, and relationship in the families from the two families and the proses of the 'Mepamit'ceremony. b). phycology implication. C). Implication on the Patiwangi ceremony gender of education perspective, such as gender inequality which can be seen on 1). Naming on parents from 'Biang to Dubiang' from 'Aji to Duaji'. 2). Naming on the bride from 'Dewa Ayu to $A y u$ '. 3). The relationship between the bride and the parents will no longer as a biological daughter, since the woman has done the Patiwangi ceremony called 'Nyerod' or lowering in caste. 4).The ceremony called 'Mepamit'is not allowed to doing it if the woman is on pregnancy.

\section{References}

Dewi, P. E. R., Suwindia, I. G., \& Sudarsana, I. K. (2018). Ethic Educations Of Leadership In Tenganan Pegringsingan Traditional Village. Vidyottama Sanatana: International Journal of Hindu Science and Religious Studies, 2(2), 269-275.

Hamidi. 2004. Metodologi Penelitian Kualitatif. Malang: UUM Press

Komang Arniati, M.Ag, Dra.Ida Ayu. 2008. Pandangan Gender Pada Smerti Dalam Perkembangan Modern. Surabaya: Paramita

Miarta Putra, I Nyoman. 2009. Mitos-Mitos Tanama Upakara. Denpasar : PT Pustaka Manikgeni

Pinandita, I Gusti Ngurah Made Suryadnya. 2013. Inti Sari Yajna dalam ajaran Hindu. Surabaya : Paramita

Prabhupada, Bhaktivedanta Swami. 2006. Bhagavadgita menurut Aslinya. Hanuman Sakti.

Putra Pudharta, S. Ag, Ida Bagus. Lontar Catur Yuga. Pemerintah Provinsi Daerah Tingkat I Bali Pusat Dokumentasi Kebudayaan Bali.

Pemerintah Provinsi Daerah Tingkat I Bali Pusat Dokumentasi Kebudayaan Bali. 1994. Alih Aksara Lontar Lebu Guntur. Unit Pelaksana Daerah Pusat Dokumentasi Kebudayaan Bali.
Pudja, Gede. 1999. Bhagawad Gita (Pancama Veda). Surabaya : Paramita

Pudja, Gede. 2004. Manava Dharmasastra. Surabaya : Paramita

Putra Hartawan, I Dewa Nyoman. 2011. Uang Kepeng Cina Dalam Ritual Masyarakat Bali. Denpasar : Pustaka Larasan

Rai Ketu,BA, A.A.Gede. 2009. Pendidikan Agama Hindu. Gianyar "MGMP Agama Hindu.

Raka Mas, Drs. A.A. Gede. 2013. 33 (Tiga Puluh Tiga) Hal yang dapat mempengaruhi dan merubah kehidupan. Surabaya : Paramita

Sudharta, M.A, Tjok Rai \& Oka Punia Atmaja, Drs, Ida Bagus. 2001. Upadesa tentang Ajaran-Ajaran Agama Hindu. Surabaya : Paramita

Sri Swami, Sivananda. 2003. Intisari Ajaran Hindu. Surabaya : Paramita

Sudarsana, MBA. MM. Drs, I.B.Putu. 2010. Ajaran Agama Hindu Upacara Manusia Yadnya. Denpasar : Yayasan Dharma Acarya.

Sudharta, Tjok Rai. 2006. Manusia Hindu dari Kandungan sampai Perkawinan. Denpasar : Yayasan Dharma Naradha.

Sukardana, Drs. K. M. 2008. Tri Rna tiga jenis hutang yang harus dibayar manusia. Surabaya:Paramita

Swastika. 2009. Suputra Menuju Keluarga Satyam, Sivam, Sudaram. Surabaya: Paramita

Tantra, MSc., PhD, Prof. Dewa Komang. 2014. Membaca Perubahan Bali. Denpasar:Wisnu Press.

Triguna, Yuda, Ida Bagus. 2000. Perubahan Sosial dan Respon Masyarakat Hindu Bali, Widya Satya Dharma; Jurnal Kajian Hindu Budaya dan Pembangunan. Singaraja: STIE Satya Dharma.

Wiana, I Ketut. 2002. Makna Upacara Yajna Dalam Agama Hindu. Surabaya : Paramita.

Winanti, S.Ag., M.Pd, Ni Putu. 2010. Perempuan dan Kepemimpinan Transformasional. Surabaya:Paramita. 